\title{
BEING AN INNOVATIVE AND CREATIVE TEACHER: PASSION- DRIVEN PROFESSIONAL DUTY
}

\author{
Vilma ŽYDŽIŪNAITĖ (1)*, Ander ARCE (1D) \\ Institute of Education, Education Academy, Vytautas Magnus University, K. Donelaičio str. 58, \\ 44248, Kaunas, Lithuania
}

Received 18 September 2020; accepted 9 March 2021

\begin{abstract}
The research problem relates to the lack of existing research in terms of understanding the meaning of being an innovative and creative teacher in association with a passion connected to professional duty. Research questions were the following: "What does it mean for a teacher to be innovative and creative? What makes an innovative and creative teacher?". The aim was to explore the meaning of being an innovative and creative teacher through teachers' experiences. The methodology was based on integration of practical phenomenology and epistemological phenomenology. The sample consisted of ten teachers from ten innovative Basque Country schools. Data was collected by using open-ended interviews. Findings showed that the passion-driven professional duty integrates being an ambitious professional, being professional through ethical and moral actions, endeavoring to discover students' learning needs, designing learning environments, being coherent with school philosophy, and testing for improvement. Findings showed that a teacher's innovativeness and creativeness are directed to the self, professional actions, students, school, and professional development. Conclusions are focused on empirical facts that innovative and creative teachers experience the meaning of their practices through duties, which they perform with passion. Teachers' innovativeness and creativity are related to ethical, moral, professional, intellectual, social, institutional, individual, and processual needs.
\end{abstract}

Keywords: innovative and creative teacher, learning, phenomenology, school, students, teaching.

\section{Introduction}

Innovation and creativity are two separate but related key concepts, and each is required for a teacher's success. Creativity does not always drive a teacher's inventions and growth; innovation does. However, innovation does not happen without a creative teacher. Generating creativity means allowing teachers to think outside the box and go against the norm sometimes. If the teacher lets bureaucracy stop creativity, innovation will be the victim in his/her teaching (Sinay et al., 2017).

Two complex concepts are used in this paper: i) being an innovative and creative teacher and ii) passion-driven professional duty. The first concept is used as a symbol of emergent

*Corresponding author. E-mails: vilma.zydziunaite@vdu.lt; socialinistyrejas@gmail.com

Copyright $\odot 2021$ The Author(s). Published by Vilnius Gediminas Technical University

This is an Open Access article distributed under the terms of the Creative Commons Attribution License (http://creativecommons. org/licenses/by/4.0/), which permits unrestricted use, distribution, and reproduction in any medium, provided the original author and source are credited. 
expression in the form of a teacher's practices and is seen by the researchers as a relational process rather than an outcome. In this research innovativeness and creativity are seen as interconnected in a teacher's practices: the creative teacher implements the innovative steps of being the first to identify possibilities of teaching and learning. Researchers did not hypothesize the strong links between innovation and creativity, they did not seek to provide evidence of the relationship between these conceptual notions, and did not look for elements that would combine these two concepts into one complex concept of being an innovative and creative teacher. The creativity in this research was extended as an antecedent and outcome of innovativeness in a teacher's practices, and being an innovative and creative teacher in this research was perceived as natural co-existence of innovativeness and creativity in a teacher's professional life. Such an open interpretation of this complex concept allowed the researchers to be opened up to phenomenological discoveries through uncertainty, and create preconditions for the research participants to construct their meanings of being an innovative and creative teacher via interviews. The other concept emerged from phenomenological data as a discovery and the cornerstone of the meaning of being an innovative and creative teacher. Researchers resisted mechanistic and deterministic connotations of both complex concepts as they looked further than the operationalized notion of being an innovative and creative teacher. The meaning of being an innovative and creative teacher considered in this research was seen through the lens of surprising serendipity rather than planned provision (van Manen, 2014, 2016a).

Innovation in education encourages teachers and students to explore, study and use all the tools to uncover something new. It involves a different way of looking at problems and solving them. The thinking process that goes into it helps teachers and students develop their creativity in teaching and learning, and that is related to innovativeness (Ellis et al., 2019). Innovative educational practices of a teacher mean promoting active and independent learning in which students take responsibility for their own learning; allowing students to work with information in different directions and contexts; engaging students in cooperative learning in which they implement intellectual projects; and changing the organization of the class and improving social cohesiveness through students' interactions (Clarke \& Hollingsworth, 2002; Kozma \& Anderson, 2002). The innovative teacher creates something new that realizes value to others - students, teacher colleagues and the school. Innovation is realized most vividly in the form of a tool, physical benefit, or aid that solves a problem or creates an advantage (Mazur \& Duchlinski, 2020).

Research on innovative teaching covers a variety of themes: how innovative teaching impacts the learning of diverse students (Naz \& Murad, 2017); what is the influence of methods in the teaching of different disciplines (Maass et al., 2019); how effective is blended learning (Justice Kintu et al., 2017); stating that learning is a science, and that the testing of learning interventions and teaching approaches before applying these to practice, should be a requirement for improving learning outcomes (Herodotou et al., 2019); and implementing new strategies for teachers' professional development (Margalef García, 2011). These research studies focus on innovative teaching as a process and then the concept of innovative teacher emerges here as a matter of course, assuming that innovative teaching is not possible without an innovative teacher. Researchers accentuate the teacher's innovativeness as a key concept 
by assuming that only an innovative teacher is capable to act by putting things into practical reality, despite challenges and resistance, rather than just contemplating (Naz \& Murad, 2017; Herodotou et al., 2019). Innovativeness of a teacher, separate from the creativity, is seen as a compulsory or expected characteristic of teaching, and thus seen as a part of a process. The notion of creativity, if any, is used interchangeably with innovativeness without discussing the connection between these concepts.

Creativity evidences itself in a teacher's ability to solve problems with novel ideas in teaching and learning practices. A teacher's creativity is the act of conceiving something original or unusual. The key factor is that creativity remains an idea alone, not yet reality; creativity is specific to teachers as they have the possibility to communicate ideas and to act consciously (Hu et al., 2013). The creativity of a teacher includes particular skills - such as the evaluation of ideas, the capacity to select relevant ideas and to put aside irrelevant ones - or mental flexibility, defined as the ability to consider an idea from different angles and also to deviate from one idea to consider another to propose creative solutions (Davies et al., 2014; Sternberg, 2015). The creativity of a teacher is multivariate and includes cognitive, conative, emotional and environmental factors (Mumford, 2003; Zenasni \& Lubart, 2011; Hu et al., 2013; Beghetto \& Kaufman, 2014; Davies et al., 2014; Sternberg, 2015; Selkrig, 2018). A creative teacher or teacher's creativity in most research studies is seen as a capability, habit or professional feature, which is related to a teacher's courage to take risks to create unpredictable learning situations for students in order to promote their autonomy and self-confidence (Morais \& Azevedo, 2011). Innovativeness here is not seen as a component in the practices of creative teachers (D. P. Newton \& L. D. Newton, 2009). Thus a teacher's creativity is focused on students' learning, while the innovativeness focuses on teaching.

Thus innovativeness and creativeness are the capacities that need to be actively encouraged in all aspects of schooling in regard to a teacher's work. However, what innovation and creativity are, and how they may be promoted through formal teaching and learning approaches, remain contested. There are differences between teachers in terms of how they understand, perceive, discuss, conceptualize, and implement/apply these complex concepts in teaching and learning practices (Selkrig, 2018). Both innovativeness and creativeness are necessary in teaching and learning, and both translate to real revenue, which makes teaching and learning practices the teacher's professional passion. Professional passion in the literature relates to a teacher's intellectual capacities and professional identity, values and moral behaviors that characterize teaching (Flores et al., 2013a, 2013b); professional development (Flores \& Porta, 2012); the conjunction between a moral teacher's values, intellect and professional commitment (Aguirre, 2014); moral obligations, duties or values of good teaching (Porta \& Flores, 2012); being a great teacher (Porta et al., 2016); a good teacher's moral code on classroom ethos (López de Maturana Luna, 2010); and the conjunction between teaching practice and teaching ethics (Crisol Moya \& López, 2014). Unfortunately, professional passion in science courses is neither associated with teacher innovativeness and creativity, nor with duty.

Being an innovative and creative teacher is the concept, constantly thrown around in teaching practices, school personnel brainstorming sessions, teachers' meetings and/or school mission statements. There is no question that this complex phenomenon is highly prized in the fast-paced modern (innovative and creative) school, but do teachers who use the terms 
experience the difference between them (Cachia et al., 2010)? Therefore, the research question which was the direction of this phenomenological study remained relevant: "What does it mean for a teacher to be innovative and creative?". The aim of the study was to explore the meaning of being an innovative and creative teacher through the experiences of teachers.

\section{Methodology}

\subsection{Design}

Qualitative research design was chosen to study the concept behind what it means to be an innovative and creative teacher. Qualitative studies are used to explore a problem and understand its complexity by empowering individuals to tell their stories, hearing their voices and minimizing the relationship between the researcher and participants (Creswell, 2012). In this research the phenomenological approach was applied. Phenomenology serves, in an adapted way, research purposes and methodological pursuits. Being a specific research methodology, it portrays phenomena from different perspectives of those who experience them. Phenomenology is not a rigid philosophical discipline with a set of dogmas. It incorporates a variety of different versions, streams, concepts and issues, which are related to theoretical and methodological approaches and variations of phenomenology (Küpers, 2009).

This research was based on integration of phenomenology of practice by van Manen (2007) and epistemological phenomenology by Moustakas $(1990,1994) .{ }^{1}$ This integral phenomenological approach tries to contribute to the further development of the integral vision, by adding a voice to the integral adventure in phenomenological methodology (Gallagher, 1997, 2003).

Phenomenology of practice is formative of sensitive practice, issuing from the pathic power of phenomenological reflections. The concept pathic derives from pathos, meaning "suffering" and also "passion". In a larger life context, the pathic refers to the general mood, sensibility, sensuality, and felt sense of being in the world (van Manen, 2016b). Pathic knowing inheres in the sense and sensuality of our practical actions, in encounters with others and in the ways that our bodies are responsive to the things of our world and to the situations and relations in which we find ourselves (van Manen, 2014). A phenomenology of practice is challenged to free itself of calculative rationality. In fact, the primal or pre-theoretical dimensions of practice are tied into the ontology of being and knowing. What distinguishes practice from theory is not that practice applies thought or concepts technically to some real thing in the world upon which it acts. Rather, the phenomenology of practice involves a different way of knowing the world. Whereas theory "thinks" the world, practice "grasps" the world it grasps the world pathically (van Manen, 1999, 2016a). Epistemological phenomenology reflects the worldview of researchers and directs the way the study is implemented. It is how the researcher can come to know about the knowledge. Epistemological phenomenology views the world as subjective and constructed by an individual (Moustakas, 1994).

The study used phenomenology based on a non-traditional, one-version approach, but with an integral approach, combining at least two versions of the phenomenology

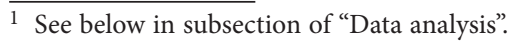


methodology. This is called the integral methodological approach (Wilber, 1997, 2000a, 2000b, 2001a, 2001b). Integral approaches emerge and respond to different contemporary challenges. The integralism provides a systematic response to complex phenomena (Zahavi, 2008). Integral phenomenological methodologies are situated in domains of knowing (Wilber, 2000b, 2001a, 2001b). Integral thinking, and corresponding research inspired by it, represents one of the most sophisticated methodological decisions for understanding and dealing with the problems and potentials. It provides a well-founded base for integral methodological decisions (Wilber, 2000a, 2006). Thus the integral methodology of phenomenology approaches the experienced phenomena in question and can be seen as an attempt to understand what experience is and means, better to say a formalized account of conscious experience and its implications (Wilber, 1997).

In this particular case, van Manen's experiential or practice-oriented orientations are the conceptual basis of the methodology. In the process of data analysis, this version was combined with the epistemological version of Moustakas, a phenomenological version of acting and the social world having various provinces of meaning. Therefore, an integral phenomenological procedure of qualitative data analysis ${ }^{2}$ has been formed and implemented. Such an integral methodological solution creates preconditions for the development of the approach that one methodological version may not be able to "serve" scientific problems through research solutions. Integral methodological pluralism links with advanced phenomenology, and pheno-practice provides a refined epistemological orientation, which allows developing innovative conceptions of qualitative research, and a more inclusive understanding of knowledge (Küpers, 2005a).

Thus, hearing a teacher's lived experience is important to understanding what it means to be innovative and creative. Interpreting the innovative and creative teacher's practices and finding common characteristics of an integrated innovative and creative teacher's being added value to this investigation (van Manen, 2016b). Researchers aimed to clarify the meanings upon which innovative and creative teachers' experiences are grounded regarding their daily practices by disclosing essences, of what "it is", without which it might not be what "it is", such that it always questions the true nature or meaning of a thing.

\subsection{Sample}

In this research, two-round sampling was applied (Tillé, 2006).

The first round was conducted for the selection of schools, here applying purposeful intensity sampling, which in this research meant institutional level information-rich cases that manifest the phenomenon intensely (Palinkas et al., 2015), such as the innovative schools of the Basque Country from the Euskalit network (2018). These schools are constantly evolving and looking for best and innovative practices to apply in their institutional practices. Some of these schools are rewarded because of the quality teaching service they offer. Furthermore, three of the schools are ranked in the top ten schools at national level. The schools which participate in the Euskalit network (2018) were contacted and agreed to help during the research and to support it. These schools were from different parts of the Basque territory,

\footnotetext{
${ }^{2}$ See below in subsection of "Data analysis".
} 
creating a broader picture of the Basque educational system. Thus, in total ten schools were positive regarding participation in the research.

The second round focused on the individual teacher level and was based on key informant sampling: a key informant, as a result of their skills and expertise within the school, is able to provide more information and a deeper insight into what is going on around them (Kemper et al., 2003) in regard to the phenomenon of "being an innovative and creative teacher". Thus the responsibility for choosing teachers was delegated to the schools themselves, as researchers did not know personally the profile of teachers in the organisations. The schools proposed those teachers who were considered innovative and creative according to the following characteristics that are the requirement of the key informant sampling: the role of a teacher as innovative and creative at school community; his/her knowledge and experiencebased authority at the school; willingness to participate in the research; communicability, and being unbiased (Onwuegbuzie \& Leech, 2007). All these characteristics were discussed with the Euskalit network schools which decided to take part in the research. This two-round sampling strategy allowed the researchers to select a small number of rich cases that provide in-depth information and knowledge of a phenomenon of interest (Tillé, 2006) and ensured impartiality and objectivity of sampling. Factors like age, gender, working experience, etc. were not a requirement for sampling, as it was assumed that the phenomenon of "being an innovative and creative teacher" does not depend on demographic factors, and having variety would furnish the research with wider and richer experiences (Rinkevich, 2011).

Finally, 10 teachers were recommended by their schools to participate in the research, but their decision to participate was based on free will. Thus, in total 5 male and 5 female teachers participated in the research from different age groups (from 25 to 60 years old), and all of them worked all their career in the educational field at schools from 15 to 30 years. Each teacher represented a different school. Thus, overall, 10 teachers participated from 10 schools.

\subsection{Data collection}

Data collection was carried out in spring and autumn of 2019. Phenomenological research involved multiple focused interviews that rely on participants' memories and reflections to revisit experiences (Lauterbach, 2018).

The interview is both a method and a technique (Guerrero-Castañeda et al., 2017). The interview was a dialogue-based meeting between researcher and research participant, an open dialogue between two people, which permits the apprehension of a phenomenon via language, because the phenomenon was transmitted via the speech of the interviewee language. In the interview setting, reciprocity meant that the interviewees were encountered as an autonomous "you" and that the interviewers were also encountered as a "you", such that both these "you"s developed each other's understanding and perspectives (Høffding \& Martiny, 2016). The researchers listened, captured and coexisted with the phenomenon. The interview content was sustained by research participants regarding the experience(s) they had at some point in their professional life and have codified and stored it in their consciousness to which they gave authentic meaning (de Chesnay, 2015). 
Basque schools use two official languages in their curriculum, Basque and Spanish. As one of researchers uses both languages, teachers received two possibilities to provide interviews in their native language. It was assumed that using the native language would help in the communication and sharing of the lived experiences of innovative and creative teachers, and therefore, would give meaningful information to researchers. Then, the interviews, which were conducted in native language, were translated into English.

All the interviews were open-ended, which meant starting with key questions and then following the text provided by the interviewees and relating their narratives to the key questions that are interrelated with research questions of the study. The interview questions were the following: "What does the requirement of the school to be an innovative and creative teacher means for you? Do you consider yourself as an innovative and creative teacher? How do you experience your (not)being an innovative and creative teacher?"

The shortest interview was 1 hour 23 minutes, and the longest - 2 hours 11 minutes. The mean of duration of all received interviews was 1 hour 02 minutes.

\subsection{Data analysis}

In order to understand the meaning provided in interviews a thorough analysis was conducted by investigating the way knowledge comes into being (Chenail, 2012) of innovative and creative teachers' practices. This phenomenological analysis was heuristic by seeking to explain the essence of innovative and creative teachers' experiences, based on reduction and constitution of meaning (Eddles-Hirsch, 2015). Researchers' notes and comments were generated at the end of making transcriptions of each interview. These field notes consisted of feedback, comments, perceptions, doubts, appointments etc. that helped to analyze and interpret the interview texts.

Researchers have not developed their own phenomenology but have avidly embraced a form of phenomenology which developed around them and which appeared to serve their purposes. Integral phenomenology is the new phenomenology (Dowling, 2007): the combination invites further research on developing an integral methodological pluralism which recognizes and investigates embodied multiple realities, while acknowledging and incorporating different ways of knowing (Küpers, 2005b). So van Manen's (2014) phenomenology of practice is commonly used in conjunction with other contemporary influences in phenomenological research studies. In this study, van Manen's version was integrated with Moustakas' (1994) version by assigning each researcher a sequence of first and second rounds of data analysis:

1. In the first round the qualitative phenomenological data analysis integrated two approaches by implementing two rounds of data analysis. Thus, the first round was based on van Manen's (1999, 2007, 2014, 2016a, 2016b) approach, which encouraged researchers to craft the texts in order to develop the structure of meaning of texts or themes, and consisted of four steps: i) uncovering thematic aspects, ii) isolating thematic statements, iii) composing linguistic transformations, and iv) gleaning thematic descriptions. Phenomenology asks for that which makes a some "thing" what it is - and without which it could not be what it is (van Manen, 2007); 
2. The second round was based on the epistemological phenomenological approach of Moustakas $(1990,1994)$ and consisted of four steps:

2.1. Listing and grouping, reducing and eliminating (determining the invariant constituents by testing each expression by answering these questions "Does it contain a moment of the experience that is necessary and sufficient for understanding it?". If both answers were "no", then the expression was eliminated. Other expressions which were eliminated were ones that included overlapping, repetitive, and vague language);

2.2. Clustering and thematizing the invariant constituents (the related invariant constituents of experience were clustered into a thematic label; these clustered and labeled constituents were the core theme of the experience);

2.3. Final identification of the invariant constituents and themes by application through checking the invariant constituents and themes against the complete record of the participant and asking the following questions: "Are they expressed explicitly in the complete transcript? Are they compatible if not explicitly expressed?". If they were not explicit or compatible, they were treated as not relevant to the participant's experience and were deleted; 2.4. Using the relevant, validated invariant constituents and themes, and constructing a textual description for each participant of the experience by including verbatim examples from the transcribed interviews.

Both analytic rounds were the way of integrating two qualitative interrelated phenomenological approaches that enriched data analysis process through which methodological validation and trustworthiness were implemented as compulsory principles in qualitative research (Connelly, 2016).

\subsection{Research ethics}

Research ethics in this research focused on two dimensions: participant's world and researcher's world (Orb et al., 2001; Dahlberg et al., 2008; Dahlberg, 2006; Mauthner et al., 2002; Long \& Johnson, 2007; Mortari, 2008; Dale Bloomberg \& Volpe, 2019; Yin, 2013) as an ethical rigor in phenomenological study (Cypress, 2017):

- Participant's world. Nuances surrounding participant recruitment and decisions to participate did not involve issues related to socio-cultural and political context, trust, knowing and being known, and reimbursement of participants' time and expenses. When approaching participants, the researchers emphasized the importance of access to official gatekeepers, in our case - representatives of schools-participants administration. ${ }^{3}$ This is because only through these gatekeepers researchers gained access to potential participants - teachers. Potential ethical conflicts did not exist because researchers maintained impartiality by selecting schools and letting those schools give the free choice to teachers regarding participation in the research; thus researchers had neither power effect nor put any pressure on participants' choices regarding participation and free will to provide information via interviews. This created an atmosphere of trust between participants and researchers (Long \& Johnson, 2007);

- Researchers ensured participants were fully aware of what they were getting into, so that they gave an informed consent prior to participating, as researchers were

\footnotetext{
$\overline{3}$ See above in subsection "Sample".
} 
obliged to balance the value of knowledge to be acquired against any anticipated distress or other adverse experience for participants. A standard method for informing participants was the use of an informed consent sheet with content about the aim, duration of research, nature of participant recruitment, and how the anonymity and confidentiality of the participants will be ensured (Mauthner et al., 2002). Researchers refrained from collecting data that was not relevant to their research questions to avoid collecting data more sensitive than was needed (Cypress, 2017);

- Researcher's world. The faithfulness to the phenomenon is the principle of all principles in phenomenological research. Working out this principle means describing the phenomenon as it appears and as it manifests itself to consciousness (Mortari, 2008). Emptying the mind is the other ethical principle in phenomenological research. "Emptying" in our research did not mean falling into absolute nothingness, but, rather, lightening the mind of what it means to do the epoché (Dahlberg et al., 2008). It was implemented intellectually by bracketing the validity of already-confirmed knowledge and hearing, perceiving and discovering the otherness in interviews, data collection, analysis and interpretation processes (Dahlberg, 2006; Cypress, 2017). Transparency of research procedures was crucial for establishing trustworthiness and credibility (Dale Bloomberg \& Volpe, 2019). It included clear documentation of research procedures and developing a study protocol that can be easily followed. Trustworthiness was ensured by triangulating data analysis (implementing integration of two methodological versions and verifying emerging themes and its content by both researchers, and using researchers' notes). Having multiple sources of data helped researchers to capture a broader range of research participants' perspectives (Yin, 2013; Cypress, 2017). Research credibility was implemented by accurate presentation of participants' experience-based perceptions, feelings, and actions through performing data collection, analysis and interpretation, and providing findings through emerged qualitative themes from analyzed interview texts (Yin, 2013). Before data collection both researchers discussed possible personal biases and came to the conclusion that neither has any regarding the particular study. In this research confirmability involved reflective conversations of both researchers in order to link the data received from the study participant responses and the emerged qualitative themes, which represent the experience-based meanings of research participants. It allowed for researchers' introspection regarding the data collected (Dale Bloomberg \& Volpe, 2019; Cypress, 2017).

\section{Findings}

The theme passion-driven professional duty emerged from empirical qualitative data with regard to the meaning of being an innovative and creative teacher. This theme was created through integration of subthemes such as being an ambitious professional, being professional through ethical and moral acting, endeavoring to discover students' learning needs, designing learning environments, being coherent with school philosophy, and testing for improvement. These subthemes show that teacher's innovativeness and creativeness is directed to the self, professional actions, students, school, and professional development. A teacher's innovativeness and creativeness emerges by acting, learning through and in practice, being connected to students through professional relationship, perceiving school philosophy and being loyal to it, reflecting the teaching and learning processes through trying, testing, and 
Table 1. Phenomenological structure of being an innovative and creative teacher (source: created by authors)

\begin{tabular}{|l|l|}
\hline \multicolumn{1}{|c|}{ Sub-themes } & \multicolumn{1}{c|}{ THEME } \\
\hline Being an ambitious professional & PASSION-DRIVEN PROFESSIONAL \\
DUTY
\end{tabular}

what live experimenting means in the professional field with passion and duty. Thus the phenomenological structure of the phenomenon being an innovative and creative teacher is provided in Table 1.

\subsection{Being an ambitious professional}

Passion and ambition, concepts that come together because they are interconnected within a teacher's innovative and creative practices (Teacher C):

"I am very curious, I am passionate about teaching and learning. I think this is a part of my teaching duty to be passioned. When we introduced the tablets, I was a bit stacked, saying, 'Yes, you don't have to fear, it is another resource'. I am curious, I read a lot in the internet, and if we have to introduce the tablets, I wasn't interested in introducing the typical apps, the ones that are done for mathematics, I wanted to create them. I looked for an app in which I could introduce my contents, I did many timing-taps. I don't fear those things, when I see something new, I like it, because it is a challenge. And I know I will learn from it and will develop myself" (Teacher B).

Ambitious, eager to learn, to improve, to help students, to break with the status quo, not conforming with what is assumed. Teachers are aware of the reality in which they are, and they know that to reach where they want, they need to experience personal accomplishment in order to be innovative and creative (Teachers A, E):

"Fear paralyzes. The uncertainty, fear for the unknown. I am a straightforward person. If I don't know about tailoring, I will learn; if I don't know using the tablets, I will learn. The eager to learn, the spirit. But the same is in real life. Why some people cross the river and others don't, why they jump into the pool. Why do I enter in a technologically innovative project? Because I jump into it. I like it? Yes, but a priori, I jump into it. I want to discover, I want to know, I want to see [...] I am passionate about teaching. This is my duty" (Teacher E).

Fear and conformism are the enemies of the professional ambition: interview participants (Teachers A, E, F, G, J). mentioned the word "fear", referring to it as the enemy fighting against being an innovative and creative teacher. On the other hand, ambition, passion and duty were the key concepts they (Teachers A, B, C, G, H) referred to as the drivers for innovation and creativeness by seeking change in teaching and learning. 


\subsection{Being professional through ethical and moral acting}

Teachers' concern regarding the importance of their jobs and duties, the relevance they have to students and society, and the awareness of the influence and impact they have on students' success and performance. This is what drives teachers' professional innovativeness and creativeness (Teachers $\mathrm{C}, \mathrm{E}, \mathrm{G}$ ):

"[...] Having a sense of professionalism and passion to teach. I live for it; I am the professional. [...] As a professional I have responsibilities and duties. They don't pay me just for coming, they pay me for doing the teaching in the right way. They pay me to be every minute with the student and to improve lifelong learning. [...] having the attitude, the desire, values, being able to work in groups, in networks, being flexible" (Teacher $\mathrm{H}$ ).

Teachers do not feel they do their job only for the school, students and society, they do it also for themselves (Teachers A, J). For teachers being innovative and creative means having a strong moral sense of teaching profession (Teachers C, E, G, H, J). Teachers' morality and professionalism is what drives their actions and motivation, and what gives meaning to their lives. Teachers' personal ethics towards the profession is translated into energy to accomplish their duties and responsibilities innovatively and creatively (Teachers B, F):

"I consider myself as a professionally passioned person and as a teacher who loves the work and who tries to accomplish it in the best possible way. Surely, with less effort I would be able to do it, and other people would have the perception that I am doing it in the ethically right way. But this is not how I think and I feel that I should do it. The capacity for self-improvement to do it better, to live here and now, and say: what do they [students] need, I will prepare by myself. It is never enough to be "ready", and the teacher is someone who is in constant recycle of learning [...] Knowing doesn't occupy space. I need to be innovative and creative and act morally right, ethically right, I mean" (Teacher B).

Findings show that the teacher as a thoughtful and acknowledged professional has a clear image of the ethical and moral self, his/her role, and creating personal ethics within the school community (Teachers A, B, E).

\subsection{Endeavoring to discover students' learning needs}

Innovative and creative teachers are constantly questioning regarding their own and students' behaviors, practices, attitudes, and resources (Teachers B, D):

"Being innovative and creative is being someone who questions with passion and duty. It questions about doing, what is working and what not, what students need. And then seeks. Seeks to improve, and doing for students. Students have interest in how we do what we do. And I look for solutions or methodologies that help reaching everyone in a class. [...] I think we have to look for ways to reach all students" (Teacher C).

Questioning, looking for answers and reflecting on them is what leads teachers to be innovative and creative. Teachers reflect in conjunction with the understanding of the identified student and school needs that enable teachers to look for solutions and use the resources to be innovative and creative in order to provide support for students (Teachers I, J). Furthermore, innovative and creative teachers understand that every student is different, and each student's 
learning needs could be different (Teachers A, B). Therefore, this student-centered approach assumes that every innovative and creative teaching and learning practice is the premise to reach students and to help them to achieve their learning objectives (Teachers $B, G$ ):

\begin{abstract}
"The role of the teacher is, in my opinion, guiding students with passion and duty. Having everything prepared so they are responsible for their learning. In a way, we have to bring them, guide them. I am the companion, who facilitates resources to reach the learning point I want and which students can reach. We used to think that there are objectives which students couldn't reach. But no. We as teachers are the ones who put these limits. I think, students can reach in learning wherever and whatever they want as long as we guide them and bring them the resources they need to reach the particular point" (Teacher C).
\end{abstract}

Findings showed that the student-centered approach leads a teacher's professionalism and professional actions (Teachers A, C, H).

\title{
2.4. Designing learning environments
}

Innovative teachers nowadays are creators. They analyze their context and adapt their knowledge, experience and tools to design learning environments to encourage, motivate, stimulate and create the conditions for the students to learn (Teachers D, E, F). They know what students need and how to help them transfer the knowledge teachers want them to learn (Teachers E, G). They seek to grow their students holistically by giving to them the learning tools (Teachers D, H, J). Planning is therefore very important. Even if innovative and creative teachers are spontaneous, but they adapt the tools, usually good planning is helpful to implement their innovativeness and creativeness (Teachers $C, D, G$ ):

"I was thinking about the last project [...] We had to work on nature [...] We came up with the idea of working in a project about Harry Potter. Furthermore, we asked the students, which project do they want to do, what do they want to work on. There came up lots of ideas and one of them was Harry Potter. Then, it was a task for my parallel and me, working on Harry Potter by "making potions" with learning medicinal plants, Harry Potter's pets, animals [...] I discovered passion for teaching differently and students discovered their passion to learn innovatively" (Teacher A).

Creativity for this reason is a skill that comes on to the scene. First, innovative and creative teachers need to know what they want to teach, what students need to learn. Then, they reflect on the way they will address to this learning (Teachers A, C, H). This is moment when creativity is needed, to link all those factors and design learning environments that will help students to achieve their learning objectives (Teachers E, F). Usually a last step is taken where the innovative and creative teacher evaluates and reflects on the aspects, which can be improved or changed (Teachers B, J).

\subsection{Testing for improvement}

Innovative and creative teachers are aware that even if they are competent and highly qualified, they still have lots to learn. They know being innovative is not a stationary learning process, in which you learn once and it lasts for one's whole life (Teachers A, C, E). Being inno- 
vative and creative means updating and transferring knowledge (Teachers $B, H$ ). Knowledge is only valuable when it is used, when it is practical and has a real-life value (Teachers $\mathrm{H}, \mathrm{J}$ ):

"It helps you improving your competences, the emotional ones, or the ones that teaches you how to act. You learn from everything with passion. From the worse moments, from mistakes. We must forget the fear of making mistakes. [...] well, sometimes you have to empower yourself and change, and later you will be able to see the results, or not" (Teacher G).

To achieve and develop expertise through experience, trial and error is the only way to measure and apply professional learning. To achieve this, fear or resentful attitudes have to be avoided (Teachers B, G). Trying or testing is the only way to see if any creative practice with innovation is successful and useful (Teachers C, E, F):

“The errors hurt a lot. If I can, I don't want to make mistakes. But if I make a mistake, it must be because I tried, because I was passioned to change, to create, to achieve the goal. My preoccupation is that the mistake is not a core principle. I can make mistakes in implementation [...] I haven't calculated properly, but this with years you go fixing it. If I designed the lesson in a way that in general education hasn't work properly, I don't care. Let's evaluate how we implemented the process. This attitude is based on innovative and creative designing and striving to improve with passion" (Teacher J).

However, it does not mean innovative and creative teachers do not care about mistakes. If they can, they avoid making mistakes. But what enforces and lets them act without fear is the passion and the duty with intelligent strategy that what they are trying to implement will be beneficial for students and/or the school (Teachers F, G, I). Innovative and creative teachers are confident and this is the reason why they do not fear mistakes, because they know that this is a part of teaching and learning processes, and that they will learn from it (Teachers A, B, E, J).

\subsection{Being coherent with school philosophy}

Innovative and creative teachers do not forget the school as a teaching and learning place and space in which they work:

"We have been having lots of changes, and for the place I have been set to, the technological observation centers responsible for technological innovation, I had the luck of doing something I like, making it flourish in other people. Not just colleagues. Inside the musical domain, in which I am submerged inside of a new methodology. Inspiring my students has been a pleasure. Because inspiring the students on something you love, there is no better reward. You let the germ inside and it will flourish. I am passioned to teach and create" (Teacher D).

Teachers feel connected with students, the school community through leading teams, and students' families (Teachers C, D, H, J). Innovative and creative teachers experience and perceive the school as a whole. This connection in terms of ideology and belonging is another important source of energy, what motivates them to be innovative and creative. Innovative and creative teachers are aware of what is asked of them, and they feel connected to the school value-based principles (Teachers B, C, E):

"Making the book, or the video tutorials, or the scape-room [...] The feeling of doing them has been of pride, knowing you are doing something good, and something 
coherent with school philosophy. [...] Because now it's not just my ideology and step away from school action plan. The school is seeking to be innovative. This is my duty and passion to be within" (Teacher J).

The findings explored that the innovative and creative teacher is in connection with the resources, tools and attitudes at the school.

\section{Discussion}

Passion-driven professional duty is the meaning of a teacher being innovative and creative at school.

Innovative and creative teachers are ambitious to perform their activities ethically as they feel passion for their profession. Research findings showed that teachers' professionalism drives their behavior and perceptions, and is transformed into implementation of their teaching; for them this means passion-driven professional duty. Teachers feel passion for their job, and this is related to their motivation to be innovative and creative. These findings coincide with Serin's (2017) attitude that passion is showing a willingness through spending time and energy on an activity that someone believes is important, and it is a motivation, seeking the new and having a willingness to learn.

For teachers, being innovative and creative at school means being committed to the values and morality of the profession, and the school. Findings showed that, for teachers, professional duties performed ethically do not impede their professional passion for teaching. As Serin (2017) mentions, passion, which is based on commitment, is at the heart of effective teaching and creates motivation, hence encouraging teachers to act ethically in their profession.

In our research, innovative and creative teachers see the school as a space for learning and working as they experience the communion with students and the whole school community; for them it means passion-driven professional duty. The teachers' connection with the school culture and values directs them to be innovative and creative. Mincu (2015) relates innovative and creative teachers to the concept of quality, and then widens the innovativeness by integrating educational change, teacher quality and effectiveness, school improvement, equity, and the role of research. Our research findings show the importance of belonging to the school community and giving priority to learning. Adding the idea of Serin (2017), passionate teachers can create excitement that influences learning.

Innovative and creative teachers, who act with passion and are professionally dutiful and strongly committed to their work, can inspire their students to learn with desire (Serin, 2017). Our research explored how innovative and creative teachers are constantly questioning their own and students' learning needs, which are different. According to Naz and Murad (2017), teaching and learning are exemplified by student diversity in regard to culture, religion, family background, region, and schools where they have been studying. Due to such diversity, students' learning needs are also becoming increasingly diverse. A new challenge is to look for ways of teaching that can address their needs. To respond to such diverse needs of students, different innovative and creative teaching and differentiated strategies and methods are being used by the teachers in their classes. Findings of our research support these ideas; as research participants, innovative and creative teachers said they believe that a student- 
centered approach is the premise to reach students, and leads teachers' professional actions. For teachers, all this impossible without passion-driven professional duty. Innovative and creative teachers who are professionally dutiful bring to students a passion to learn (Serin, 2017).

From our research it is clear that passion and ambition for innovative and creative teachers are notions that come together as they are interconnected in a teacher's innovative and creative professional practice. Fear and conformism are notions contradictory to a teacher's professional ambition. Professionally passionate teachers are dutiful and courageous professionally through creating an innovative learning environment in order to increase the learning potential of students (Serin, 2017).

Designing learning environments for research participants means the intellectual (developing knowledge through contextualisation), the pedagogical (teaching and learning tools and practices), and the social (teacher-student interactions), aiming for positive educational outcomes. This indicates their passion-driven professional duty. Thus it means that innovative and creative teachers are focused on the integration of a cognitive approach, where the student is a more active participant in learning, with a constructivism-based approach, where learning is collaborative and teachers are known as facilitators and not instructors. Such approaches are essences of primary importance in designing learning environments. Thus, our findings add social, intellectual and pedagogical value to the already-existing understanding that designing learning environments means classroom arrangements (easy access to all the materials, creating separate workspaces), things to consider in the classroom layout (students should easily be able to move around the classroom to access all the different areas and to get the materials or resources they need for their learning) (Prameswari \& Budiyanto, 2017), and the physical environment of the school (Manca et al., 2020).

Our findings show that innovative and creative teachers use testing and trying for improvement, which includes improvement of teaching and learning. For innovative and creative teachers, continuous learning and experimenting is strong evidence of passion-driven professional duty. This fits the findings of Darling-Hammond (2001), who found that teachers do not avoid trials, testing, or changing, and they do it for the improvement of their professional practices for the best of students' learning.

In our research, being an innovative and creative teacher means connectedness with students and the school community. Thus, for them the school means its entirety, because of a school philosophy which embodies the leading professional role of a teacher, and the teacher's coherence with the school philosophy, through professional passion-driven duty. These findings match the idea of the teacher's leadership at school in regard to the teacher's coherence (Richmond et al., 2019). But these our research findings also expand the understanding about a teacher's coherence as it is seen as a part of being an innovative and creative teacher. Typically teachers' coherence in research literature is not related to teachers' innovativeness and creativeness; mostly it is related to culturally and emotionally responsive practice (which in our research findings is manifested through teachers' professionalism and duties, morality and ethics) and the school quality, and evaluation (Lindvall \& Ryve, 2019). Our findings are supplemented with empirical evidence that a coherent innovative and creative teacher is constantly in connection with the resources, tools and attitudes at the school; these interconnections are part of the passion-driven professional duty as a meaning of being an innovative and creative teacher. 


\section{Conclusions}

Being an innovative and creative teacher means passion-driven professional duty through achieving and implementing innovative and creative processes, which are directed and focused on educational actions and activities, students' learning and school innovativeness for improvement. Being an ambitious professional, being professional through ethical and moral acting, endeavoring to discover students' learning needs, designing learning environments, being coherent with school philosophy, and testing for improvement, makes the teacher being innovative and creative as essences that are interrelated with the teacher's innovativeness and creativeness through his/her professional passion, professionalism, duty, morality and improvement. Being an innovative and creative teacher is experienced through participating in school improvement by being a part of the school community and seeking change together with colleagues and students; giving priority to students' learning needs; connecting passion and ambition, as opposed to fear and conformism.

The professional passion is supported by the professional duty which teachers experience towards their job as professionals, and towards themselves as individuals. Innovative teachers become creative because of being focused on students' learning needs, coherence with school philosophy, a teacher's ethical and moral actions, a teacher's professional ambitions and capabilities to design learning environments ad hoc, and a teacher's courage to test and try for improvement - personal (self and students'), school community and school as an institution.

Integration of a passion and duty for teachers as professionals is an intellectual and moral intervention to promote their professional coherence. Innovative and creative teachers experience the meaning of their practices through passion for their job with the focus on duty. This gives them the energy and motivation for innovative and creative actions. Teachers' professionalism is connected with innovation and creativity, which is related to ethical, professional, moral, intellectual, social/interactional, institutional/school community, personal (teacher/student), processual (teaching/learning) needs. These connections encourage teachers to change, to be open-minded, and to adapt to the context and/or situation. The passiondriven professional duty is the source of energy that motivates teachers to be innovative and creative.

\section{References}

Aguirre, J. (2014). La ética y valores morales en la enseñanza universitaria desde la perspectiva de los estudiantes: conjunción de intelecto, compromiso, afecto y pasión en los profesores memorables. Revista Entramados: Educación y Sociedad, 1(1), 323-335.

Alexander, R. J. (2015). Teaching and learning for all? The quality imperative revisited. International Journal of Educational Development, 40, 250-258. https://doi.org/10.1016/j.ijedudev.2014.11.012

Beghetto, R. A., \& Kaufman, J. C. (2014). Classroom contexts for creativity. High Ability Studies, 25(1), 53-69. https://doi.org/10.1080/13598139.2014.905247

Cachia, R., Ferrari, A., Ala-Mutka, K., \& Punie, Y. 2010). Creative learning and innovative teaching: final report on the study on creativity and innovation in education in the EU member states. Joint Research Center Scientific and Technical Reports. Publications Office of the European Union. 
Chenail, R. J. (2012). Conducting qualitative data analysis: reading line-by-line, but analyzing by meaningful qualitative units. The Qualitative Report, 17(1), 266-269.

Chesnay, de M. (Ed.). (2015). Nursing research using phenomenology: qualitative designs and methods in nursing. Springer Publishing Company, LLC. https://doi.org/10.1891/9780826126870

Clarke, D., \& Hollingsworth, H. (2002). Elaborating a model of teacher professional growth. Teaching and Teacher Education, 18(8), 947-967. https://doi.org/10.1016/S0742-051X(02)00053-7

Connelly, L. M. (2016). Trustworthiness in qualitative research. Medical Surgical Nursing, 25(6), 435436.

Creswell, J. W. (2012). Qualitative inquiry and research design: choosing among five approaches. Sage Publications, Inc.

Crisol Moya, E., \& López, R. (2014). "Práctica docente versus ética docente". Hacia la mejora de la práctica docente a partir de la ética profesional. Journal for Educators, Teachers and Trainers, 5(2), 24-35.

Cypress, B. S. (2017). Rigor or reliability and validity in qualitative research: perspectives, strategies, reconceptualization, and recommendations. Dimensions of Critical Care Nursing, 36(4), 253-263. https://doi.org/10.1097/DCC.0000000000000253

Dahlberg, K. (2006). the essence of essences - the search for meaning structures in phenomenological analysis of lifeworld phenomena. International Journal of Qualitative Studies on Health and WellBeing, 1(1), 11-19. https://doi.org/10.1080/17482620500478405

Dahlberg, K., Dahlberg, H., \& Nyström, M. (2008). Reflective lifeworld research. Studentlitteratur.

Dale Bloomberg, L., \& Volpe, M. (2019). Completing your qualitative dissertation: a road map from beginning to end. Sage Publications, Inc.

Darling-Hammond, L. (2001). Teacher testing and the improvement of practice. Teaching Education, 12(1), 11-34. https://doi.org/10.1080/10476210123029

Davies, D., Jindal-Snape, D., Digby, R., Howe, A., Collier, Ch., \& Hay, P. (2014). The roles and development needs of teachers to promote creativity: a systematic review of literature. Teaching and Teacher Education, 41, 34-41. https://doi.org/10.1016/j.tate.2014.03.003

Dowling, M. (2007). From Husserl to van Manen: a review of different phenomenological approaches. International Journal of Nursing Studies, 44(1), 131-142. https://doi.org/10.1016/j.ijnurstu.2005.11.026

Eddles-Hirsch, K. (2015). Phenomenology and educational research. International Journal of Advanced Research, 3(8), 251-260.

Ellis, V., Souto-Manning, M., \& Turvey, K. (2019). Innovation in teacher education: towards a critical re-examination. Journal of Education for Teaching: International Research and Pedagogy, 45(1), 2-14. https://doi.org/10.1080/02607476.2019.1550602

Euskalit. (2018). Excellence in the basque country. https://www.euskalit.net/en/

Flores, G., Álvarez, Z., \& Porta, L. (2013a). La buena enseñanza en la educación superior: profesores memorables y valores morales. Magistro, 7(13), 81-108. https://doi.org/10.15332/s2011-8643.2013.0013.03

Flores, G., Yedaide, M. M., \& Porta, L. (2013b). Grandes maestros: Intimidad entre la educación y la vida. Pasión por enseñar en el aula universitaria. Revista de Educación, 4(5), 173-188.

Flores, G., \& Porta, L. (2012). La dimensión ética de la pasión por enseñar. Una perspectiva biográfico-narrativa en la Educación Superior. Praxis Educativa, 16(2), 52-61.

Gallagher, Sh. (1997). Mutual enlightenment: recent phenomenology in cognitive science. Journal of Consciousness Studies, 4(3), 195-214.

Gallagher, Sh. (2003). Phenomenology and experimental design. Journal of Consciousness Studies, 10(9-10), 85-99. 
Guerrero-Castañeda, R. F., Oliva Menezes, de T. M., \& Ojeda-Vargas, G. (2017). Characteristics of the phenomenological interview in nursing research. Revista Gaúcha de Enfermagem, 38(2). http://www.scielo.br/pdf/rgenf/v38n2/en_0102-6933-rgenf-1983-144720170267458.pdf

Herodotou, Ch., Sharples, M., Gaved, M., Kukulska-Hulme, A., Rienties, B., Scanlon, E., \& Whitelock, D. (2019). Innovative pedagogies of the future: an evidence-based selection. Frontiers in Education 4. https://doi.org/10.3389/feduc.2019.00113

Høffding, S., \& Martiny, K. (2016). Framing a phenomenological interview: what, why and how. Phenomenology and the Cognitive Sciences, 15, 539-564. https://doi.org/10.1007/s11097-015-9433-Z

Hu, W., Wu, B., Jia, X., Yi, X., Duan, Ch., Meyer, W., \& Kaufman, J. C. (2013). Increasing students' scientific creativity: the "learn to think" intervention program. Journal of Creative Behavior, 47(1), 3-21. https://doi.org/10.1002/jocb.20

Justice Kintu, M., Zhu, Ch., \& Kagambe, E. (2017). Blended learning effectiveness: the relationship between student characteristics, design features and outcomes. International Journal of Educational Technology in Higher Education, 14(7). https://doi.org/10.1186/s41239-017-0043-4

Kemper, E. A., Stringfield, S., \& Teddlie, Ch. (2003). Mixed methods sampling strategies in social science research. In A. Tashakkori \& Ch. Teddlie (Eds.), Handbook of mixed methods in social and behavioral research (pp. 273-296). Sage Publications, Inc.

Kozma, R. B., \& Anderson, R. E. (2002). Qualitative case studies of innovative pedagogical practices using ICT. Journal of Computer Assisted Learning, 18(4), 387-394. https://doi.org/10.1046/j.0266-4909.2002.00250.doc.x

Küpers, W. (2005a). Phenomenology and integral pheno-practice of embodied well-be(com)ing in organizations. Culture and Organization, 11(3), 221-232. https://doi.org/10.1080/14759550500204142

Küpers, W. (2005b). Phenomenology of embodied implicit and narrative knowing. Journal of Knowledge Management, 9(6), 114-133. https://doi.org/10.1108/13673270510630006

Küpers, W. M. (2009). The status and relevance of phenomenology for integral research: or why phenomenology is more and different than an "Upper Left" or "Zone \#1" affair. Integral Review, 5(1), 51-95.

Lauterbach, A. A. (2018). Hermeneutic phenomenological interviewing: going beyond semi-structured formats to help participants revisit experience. The Qualitative Report, 23(11), 2883-2898.

Lindvall, J., \& Ryve, A. (2019). Coherence and the positioning of teachers in professional development programs: a systematic review. Educational Research Review, 27, 140-154.

Long, T., \& Johnson, M. (2007). Research ethics in the real world: issues and solutions for health and social care. Churchill Livingstone/Elsevier Limited. https://doi.org/10.1016/j.edurev.2019.03.005

López de Maturana Luna, S. L. (2010). Historia de vida de buenos profesores: experiencia e impacto en las aulas. Profesorado: Revista de Currículum y Formación del Profesorado, 14(3), 149-164.

Maass, K., Cobb, P., Krainer, K., \& Potari, D. (2019). Different ways to implement innovative teaching approaches at scale. Educational Studies in Mathematics, 102, 303-318. https://doi.org/10.1007/s10649-019-09920-8

Manca, S., Cerina, V., Tobia, V., Sacchi, S., \& Fornara, F. (2020). The effect of school design on users' responses: a systematic review (2008-2017). Sustainability, 12. https://doi.org/10.3390/su12083453

Manen, van M. (2007). Phenomenology of practice. Phenomenology and Practice, 1(1), 11-30. https://doi.org/10.29173/pandpr19803

Manen, van M. (2014). Phenomenology of practice: meaning-giving methods in phenomenological research and writing. New York.

Manen, van M. (2016a). Researching lived experience: human science for an action sensitive pedagogy. Routledge.

Manen, van M. (Ed.). (2016b). Writing in the dark: phenomenological studies in interpretive inquiry. Routledge. 
Manen, van M. (1999). The pathic nature of inquiry and nursing. In I. Madjar \& J. Ann Walton (Eds.), Nursing and the experience of illness: phenomenology in practice (pp. 17-35). Routledge.

Margalef García, L. (2011). Encouraging teachers' and students' innovation with the support of teacher learning communities. Center for Educational Policy Studies Journal, 1(1), 133-152.

Mauthner, M., Birch, M., Jessop, J., \& Miller, T. (Eds.). (2002). Ethics in qualitative research. Sage Publications Ltd. https://doi.org/10.4135/9781849209090

Mazur, P. S., \& Duchlinski, P. (2020). Credibility and creativity in network society. Creativity Studies, 13(1), 53-63. https://doi.org/10.3846/cs.2020.6585

Mincu, M. E. (2015). Teacher quality and school improvement: what is the role of research? Oxford Review of Education, 41(2), 253-269. https://doi.org/10.1080/03054985.2015.1023013

Morais, M. F., \& Azevedo, I. (2011). What is a creative teacher and what is a creative pupil? Perceptions of teachers. Procedia - Social and Behavioral Sciences, 12, 330-339.

https://doi.org/10.1016/j.sbspro.2011.02.042

Mortari, L. (2008). The ethic of delicacy in phenomenological research. International Journal of Qualitative Studies on Health and Well-Being, 3(1), 3-17. https://doi.org/10.1080/17482620701747392

Moustakas, C. (1990). Heuristic research: design, methodology, and applications. Sage Publications, Inc. https://doi.org/10.4135/9781412995641

Moustakas, C. (1994). Phenomenological research methods. Sage Publications, Inc. https://doi.org/10.4135/9781412995658

Mumford, M. D. (2003). Where have we been, where are we going? Taking stock in creativity research. Creativity Research Journal, 15(2-3), 107-120. https://doi.org/10.1207/S15326934CRJ152\&3_01

Naz, F., \& Murad, H. S. (2017). Innovative teaching has a positive impact on the performance of diverse students. SAGE Open, October-December, 1-8. https://doi.org/10.1177/2158244017734022

Newton, D. P., \& Newton, L. D. (2009). Some student teachers' conceptions of creativity in school science, Research in Science and Technological Education, 27(1), 45-60. https://doi.org/10.1080/02635140802658842

Onwuegbuzie, A. J., \& Leech, N. L. (2007). A call for qualitative power analyses. Quality and Quantity, 41, 105-121. https://doi.org/10.1007/s11135-005-1098-1

Orb, A., Eisenhauer, L., \& Wynaden, D. (2001). Ethics in qualitative research. Journal of Nursing Scholarship, 33(1), 93-96. https://doi.org/10.1111/j.1547-5069.2001.00093.x

Palinkas, L. A., Horwitz, S. M., Green, C. A., Wisdom, J. P., Duan, N., \& Hoagwood, K. (2015). Purposeful sampling for qualitative data collection and analysis in mixed method implementation research. Administration and Policy in Mental Health and Mental Health Services Research, 42, 533-544. https://doi.org/10.1007/s10488-013-0528-y

Porta, L., \& Flores, G. (2012). Valores morales en la educación superior. Abordaje biográfico-narrativo desde profesores universitarios memorables. Docencia Universitaria, 6(1), 40-59. https://doi.org/10.19083/ridu.6.37

Porta, L., Yedaide, M. M., \& Álvarez, Z. (2016). Sentidos de la pasión. Episteme, 5(6), 11-18.

Prameswari, S. J., \& Budiyanto, C. (2017). The development of the effective learning environment by creating an effective teaching in the classroom. Indonesian Journal of Informatics Education, 1(1), 79-86. https://doi.org/10.20961/ijie.v1i1.11960

Richmond, G., Bartell, T., Carter Andrews, D. J., \& Neville, M. L. (2019). Reexamining coherence in teacher education. Journal of Teacher Education, 70(3), 188-191. https://doi.org/10.1177/0022487119838230

Rinkevich, J. L. (2011). Creative teaching: why it matters and where to begin. The Clearing Hourse: A Journal of Educational Strategies, Issues and Ideas, 84(5), 219-223.

https://doi.org/10.1080/00098655.2011.575416 
Selkrig, M. (2018). Connections teachers make between creativity and arts learning. Educational Research, 60, 478-493. https://doi.org/10.1080/00131881.2018.1524715

Serin, H. (2017). The role of passion in learning and teaching. International Journal of Social Sciences and Educational Studies, 4(1), 60-64. https://doi.org/10.23918/ijsses.v4i1p60

Sinay, E., Nahornick, A., \& Graikinis, D. (2017). Creativity and innovation in teaching and learning: A Focus on Innovative Intelligence $\left(I^{2} Q\right)$ Pilot Program. Research and Information Services. Toronto District School Board. Report No. 17/18-11. Series: Fostering Global Competencies and Deeper Learning with Digital Technologies Research Series. https://www.tdsb.on.ca/Portals/research/docs/ reports/GC\%20Research\%20Series\%20\%E2\%80\%93\%20Fostering\%20Creativity\%20and\%20Innovation\%20I2Q.pdf

Sternberg, R. J. (2015). Teaching for creativity: the sounds of silence. Psychology of Aesthetics, Creativity, and the Arts, 9(2), 115-117. https://doi.org/10.1037/aca0000007

Tillé, Y. (2006). Sampling algorithms. Series: Springer Series in Statistics. Springer Science+Business Media, Inc.

Wilber, K. (2001a). A theory of everything: an integral vision for business, politics, science and spirituality. Shambhala.

Wilber, K. (2001b). The eye of spirit: an integral vision for a world gone slightly mad. Shambhala Publications, Inc.

Wilber, K. (1997). An integral theory of consciousness. Journal of Consciousness Studies, 4(1), 71-92.

Wilber, K. (2000a). Integral psychology: consciousness, spirit, psychology, therapy. Shambhala.

Wilber, K. (2000b). Waves, streams, states and self: further considerations for an integral theory of consciousness, Journal of Consciousness Studies, 7(11-12), 145-176.

Wilber, K. (2006). Integral spirituality: a startling new role for religion in the modern and postmodern world. Shambhala.

Yin, R. K. (2013). Case study research: design and methods. Sage Publications, Inc.

Zahavi, D. (2008). The phenomenological tradition. In D. Moran (Ed.), Routledge companion to twentieth century philosophy (pp. 661-692). Routledge.

Zenasni, F., \& Lubart, T. (2011). Pleasantness of creative tasks and creative performance. Thinking Skills and Creativity, 6(1), 49-56. https://doi.org/10.1016/j.tsc.2010.10.005 